University of Nebraska - Lincoln

DigitalCommons@University of Nebraska - Lincoln

4-2010

\title{
Standardized American Indians: The "Names of Indian tribes and bands" list from the Office of Indian Affairs
}

Charles D. Bernholz

University of Nebraska-Lincoln, cbernholz2@unl.edu

Follow this and additional works at: https://digitalcommons.unl.edu/libraryscience

Part of the Library and Information Science Commons

Bernholz, Charles D., "Standardized American Indians: The "Names of Indian tribes and bands" list from the Office of Indian Affairs" (2010). Faculty Publications, UNL Libraries. 207.

https://digitalcommons.unl.edu/libraryscience/207

This Article is brought to you for free and open access by the Libraries at University of Nebraska-Lincoln at DigitalCommons@University of Nebraska - Lincoln. It has been accepted for inclusion in Faculty Publications, UNL Libraries by an authorized administrator of DigitalCommons@University of Nebraska - Lincoln. 


\title{
Standardized American Indians: The "Names of Indian tribes and bands" list from the Office of Indian Affairs
}

\author{
Charles D. Bernholz \\ Love Memorial Library, University of Nebraska-Lincoln, Lincoln, NE 68588, USA; email cbernholz2@unl.edu, fax $402472-5181$
}

\begin{abstract}
The inconsistent spelling of American Indian tribal names at the end of the nineteenth century led in part to the development within the Office of Indian Affairs of an array of 270 standardized identifiers, ranging from Absaroka to Zuñi. These efforts paralleled the simultaneous improvement of a large suite of relevant terms by the United States Board on Geographic Names. Both compilations were included in style manuals published by the Government Printing Office beginning in 1900 and approved for the use of federal agencies. In 1903 and 1904, Charles J. Kappler, in the preparation of his multi-volume Indian Affairs: Laws and Treaties, made particular use of this orthography when he created new individual titles for the recognized treaties between the federal government and the Indian Nations. Even with these coordinated attempts, however, versions of the "Names of Indian tribes and bands" register during the last century suffered both exclusions from, and an addition to, the original document from the Office of Indian Affairs.
\end{abstract}

Keywords: American Indians, Names of tribes and bands, Office of Indian Affairs

"A Synonymie is a commodious heaping together of divers words of one signification." John Smith - The Mystery of Rhetorick Unveil'd (1688, p. 152).

In his annual report to the Secretary of the Smithsonian Institution for 1885-1886, John Wesley Powell, the Director of the Bureau of American Ethnology between the years 1879 and 1902, framed one of the agency's major undertakings with these words:

Names borne by one tribe at some period of its history have been transferred to another, or to several other distinct tribes. Typographical errors, and improved spelling on assumed phonetic grounds, have swelled the number of synonyms until the investigator of a special tribe often finds himself in a maze of nomenclatural perplexity (Seventh annual report of the Bureau of Ethnology to the Secretary of the Smithsonian Institution 1885-'86, 1892, pp. xxxiv-xxxv).

Beneath a caption of "Synonymy of Indian Tribes," Powell spoke of the project's importance by declaring that " $[\mathrm{t}]$ he preparation of this work, which to a great extent underlies and is the foundation for every field of ethnographic investigation among Indians, was considered of such prime importance that nearly all the available force of the Bureau was placed upon it" (p. xxxv).

As a result of the culmination of the linguistic work of James Mooney, ${ }^{1}$ Powell, ${ }^{2}$ and others, this labor was directed towards an anticipated series of "synonymy bulletins" that were to act as the building blocks of a "Cyclopedia of the American Indians" (Moses, 1984, p. 133). In its journey, the task underwent a number of proposed title changes, ranging from "Synonymy," as stated in the seventh annual presentation, to "Dictionary," and then on to "Cyclopedia," in an almost endless quest for the most appropriate descriptor of its contents (Sixteenth annual report of the Bureau of American Ethnology to the Secretary of the Smithsonian Institution 1894-'95, 1897, pp. li-lii). Overall, progress was slow and painstaking, as revealed by a note in an annual report half a decade later: "The work on the "Cyclopedia of the American Indians" has been carried forward, and a considerable part of the material has been made ready for the press" (Annual report of the Board of Regents of the Smithsonian Institution, 1898, p. 20).

The ultimate goal was a considerable one, because almost three hundred "distinct, mutually unintelligible languages" were known to have been spoken north of Mexico prior to the arrival of the Europeans (Mithun, 1999, p. 1). Eighty years after Powell's remark and in her work on the Iowa Indians, Wedel clearly stated one of the benefits of collecting such tribal synonymies:

[T] he fact of the absence in an American Indian language of a name for another Indian people has cultural connotations. Consider the case of the Arikara, Mandan, and Hidatsa of the Middle Missouri region who have no term at present for the Ioway. This suggests either lack of intercourse in the past or at a time long enough ago that the appellation had been forgotten by mid20th century informants $(1978$, p. 50$) .^{3}$

1. See his calendar history work on the Kiowa (Mooney, 1897), in which he included a prototypic tribal synonymy with source citations (pp. 148-150).

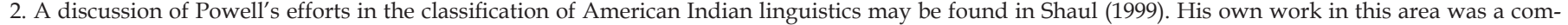
posite of studies (Powell, 1892).

3. A later synonymy, based in part on her article, was presented in the Handbook of North American Indians (Wedel, 2001, pp. 445-446). 
Similar professional sentiments, and the Department of the Interior's hunger for such a useful product, were communicated in the Annual Report for 1900 when the Commissioner of Indian Affairs, William A. Jones, declared that "[i]t has long been recognized as unfortunate that there existed no authorized standard spelling of the names of Indian tribes and bands." ${ }^{4}$ He identified several examples in which incorrect spellings or names had become generally accepted; e.g., Sac, instead of the correct Sauk, and Sioux for the more appropriate Dakota (Annual reports of the Department of the Interior for the fiscal year ended June 30, 1900, 1900 a, p. 51). A fresh collation to remove this perceived shortfall - entitled "Names of Indian tribes and bands" - documented 270 entities, including specific Hopi or Laguna villages ( $N=7$ and 2, respectively) such as Hano (Hopi village) or Paguate (Laguna village), and name or spelling directives $(N=38)$ like Absaroka, see Crow or Unkpapa, see Hunkpapa (p. 519).

In the appendix of the next Serial Set volume devoted to the same Congressional session, there was a small announcement of achievement for the year by the Board of Indian Commissioners that confirmed, under a heading of "Spelling of names of Indian tribes," that "[t]he Bureau of Ethnology and the Indian Bureau have undertaken to secure uniformity in the spelling of the names of Indian tribes and bands; and the Printing Office has published the list agreed upon by the two bureaus" (Annual reports of the Department of the Interior for the fiscal year ended June 30, 1900, 1900b, p. 687). One modification imposed by this new policy was the general omission of plurals, as recommended by the Bureau of American Ethnology, save for ten remaining examples in the array; Fox ( $p l$. Foxes) was one such use. This multidisciplinary enthusiasm was part of a concerted federal effort to develop a policy to standardize orthography within government publications. $^{5}$

A similar process for geographic names had been instituted by President Benjamin Harrison in September 1890, when he declared in his Executive Order 27-A that

[a]s it is desirable that uniform usage in regard to geographic nomenclature and orthography obtain throughout the Executive Departments of the Government, and particularly upon the maps and charts issued by the various Departments and bureaus, I hereby constitute a Board on Geographic Names... (Sixth Report of the United States Geographic Board, 1933, p. v). ${ }^{6}$

In the first report by this group of its work, the Board (United States Board on Geographic Names, 1892, p. 4) remarked that

[t]he necessity of this Board has already been amply demonstrated. During this, its first year, there have been submitted to it more than 2,000 questions and decisions have been rendered in nearly all of these cases. Shortly after it was organized, it was called upon to render decisions concerning several hundred names in Alaska, where the utmost confusion exists regarding geographic names. In this region the difficulties of transliteration of Russian and Indian names into English characters are complicated by the fact that expedition after expedi- tion visiting this region has assigned different sets of names to its geographic features.

As part of the section devoted to the "origin of and changes in geographic names" and to the absence of "any formal authority" for such identifiers, the Board further observed that "[t]he transliteration of Indian names has everywhere been a fruitful source of differences in spelling, inasmuch as no two persons understand alike or render into the same English characters the obscure sounds of Indian names" (pp. 4-5). The same remark was replicated in each of the second through the fifth Board reports between 1900 and 1921. ${ }^{7}$

The sixth Geographic Board report from 1933, however, spoke directly to "Names of Indian origin" and to how "during the seventeenth and eighteenth centuries, English spelling was notoriously unsettled and capricious" (1933, p. 12). Relevant examples of such names were presented to demonstrate these spelling differences, which were frequently based on errors introduced by multiple indigenous, as well as foreign, languages. With regard to the independent creation of the "Names of Indian tribes and bands" list in 1900 by the Department of the Interior, the Board noticed that "[t]he tribal name Mohawk appears in literature in at least 143 distinct spellings; the tribal name Oneida in 109; and the name Seneca in 110 distinct forms" (pp. 14-15). These estimates were most likely derived from the Bureau of American Ethnology's Handbook of American Indians north of Mexico (Hodge, 1906a, 1906b), the precursor of today's Handbook of North American Indians (Sturtevant, 1978-). ${ }^{8}$ Frederick Webb Hodge (1864-1956) had served as an important member of the Bureau's team, and his Handbook was initially published as Bulletin 30 of Ethnology's substantial scholarly efforts (see List of Publications of the Bureau of American Ethnology, with Index to Authors and Titles, 1971, p. 18 or http://www.sil.si.edu/DigitalCollections/BAE/Bulletin200/ 200title.htm). Later, Judd (1967, p. 41) conveyed that The Handbook of American Indians north of Mexico was "described by contemporaries as the most authoritative book on American Indians ever written." These three eastern tribes were found in The Handbook, where almost three columns were dedicated to the known names associated with the Mohawk (1906a, pp. 924-926); about one and one-half for the Oneida (1906b, pp. 125-126); and three to the Seneca (1906b, pp. 507-508)..$^{9}$ Overall, and at the rear of the second Handbook volume, a synonymy of over 2500 terms was established (Hodge, 1906b, pp. 1021-1178), in order "to record under each every form of the name and every other appellation that could be learned" (Hodge, 1906a, p. viii). ${ }^{10}$

Thus, a rich collection of federally authorized identifiers was under consideration during the last decade of the nineteenth century, for both ethnologic and geographic purposes. In the quest for the first objective, Commissioner Jones' letter of 8 August 1900 (included in a volume describing official standards for the Department of the Interior) had concluded that "[i]t has long been considered important that some single system of spelling the names of Indian tribes should be adopted and adhered to by the different branches of the Government, as geographic names have been

4. Baird (1979) presented a biographical sketch of Jones. A useful brief history of the Bureau of American Ethnology may be found in Woodbury and Woodbury (1999).

5. The continuing need for such a consistent vocabulary was voiced half a century later in Promoting uniformity of geographic nomenclature in the federal government (1947).

6. See pp. v-vi for the sequence of Executive Orders between 1890 and 1933 that defined the status and responsibilities of this Board. The unit began as the United States Board on Geographic Names, but this title was modified in 1906 to become the United States Geographic Board.

7. This series appears as the Second report of the United States Board on Geographic Names: 1890 to 1899 (1900, p. 14); the Third report of the United States Board on Geographic Names: 1890 to 1906 (1906, p. 13); the Fourth Report of the United States Geographic Board: 1890 to 1916 (1916, p. 13); and the Fifth Report of the United States Geographic Board: 1890 to 1920 (1921, p. 13), respectively.

8. See the announcement of the Handbook of North American Indians in Sturtevant (1971).

9. The corresponding Handbook of North American Indians synonymies may be seen in (Fenton and Tooker, 1978), (Campisi, 1978) and (Abler and Tooker, 1978).

10. The fundamental goal of enumerating all the possible synonyms for a tribe continued, as may be seen in the work of Mildred Mott Wedel, whose synonymy of names for the Iowa - or Ioway as she specified in her title - had "accumulated many more spellings than are present in the Handbook, a number of which are from sources that were unavailable to American researchers early in this century" $(1978$, p. 50). 
and are being decided by the board created for that purpose" (Rules and regulations governing the Department of the Interior in its various branches, 1907, p. 161). With an eye on the second task, Randall (1990) indicated that the major stimuli for such geographic contemplation grew in strength because

the need for standardization of place names became acute with the opening of the West. Exploration reports, mining claims, and land surveys often referred to rivers, mountains, settlements, and other features by different names. Some names were new; other[s] were taken from oral usage or respelled from French or Spanish documents (p. 3).

Clearly, the identification over time of indigenous peoples populating these regions had a similar mixed history: the names for the Brule band of Teton Sioux (DeMallie, 2001, p. 718) or the Cour d'Alene (Palmer, 1998, p. 313) were derived from the French, while those of the Mescalero Apache (Opler, 1983, p. 419) and for the collective Pueblo (see, for example, Pojoaque Pueblo in Lambert, 1979, p. 324) were of Spanish origin. All four terms - Brulé, Cour d'Alene, Mescalero, and Pojoaque - were presented in Interior's "Names of Indian tribes and bands" list in 1900, and - with the same spellings - in the Handbook of American Indians north of Mexico (Hodge, $1906 a$, p. 166 ; 1906b, p. 594; 1906a, p. 846 ; and 1906b, p. 274, respectively). The Cour d'Alene were purposely placed under the Skitswish, because "[t]he name Cour d'Alene (French 'awl-heart'), by which they are popularly known, was originally a nickname used by some chief of the tribe to express the size of a trader's heart" (1906b, p. 594). Skitswish is the traditional name for the tribe (Palmer, 1998, p. 325).

Beyond the uses implicit in various national ethnologic and geographic endeavors, the need for standardization was apparent in Congress itself. The Journal of the Senate, for 20 December 1881, misspelled both Mescalero and Apache in a bill submitted by Senator Edward Henry Rollins (R-NH) for "Doctor Daniel M. Appel, of the United States Army, to receive pay for discharging the duties of physician to the Miscalero Apaché Indian Agency, New Mexico" (Journal of the Senate of the United States of America, being the session specially called Monday, October $10,1881,1881$, p. 135). ${ }^{11}$

In his August 1900 directive to the employees of the Office of Indian Affairs, Commissioner Jones acknowledged that the Government Printing Office's Manual of Style Governing Composition and Proof Reading in the Government Printing Office Together with Decisions of the Board on Geographic Names (1900) was the publication containing the freshly prepared "Names of Indian tribes and bands" list, in conjunction with the new geographic standards defined by the Board on Geographic Names. Jones announced an additional explanation for the implementation of such spellings within Indian Affairs, and for receiving supplements to the list: "If other names ought to be added to the list the Office would be glad to receive additions and suggestions, to be considered when another edition of the list shall be issued" (Rules and regulations governing the Department of the Interior in its various branches, 1907, p. 161). However, the most important transition was reserved for the revised spellings; the Commissioner cautiously offering that an attempt has been made to take a middle course, to spell phonetically, so far as practicable, and yet to retain spellings which have long obtained in treaties and legislation and such as have been used in geographic terms, or are of foreign origin. It is not claimed that the spelling herewith adopted is as consistent or as scientific as might be desirable; but at this late day the main thing to be attempted is to secure uniformity in the spelling of Indian names, since thorough reform in their spelling is no long practicable (p. 161).

In this approach, the orthography made use of the letter $e$ with acute for the terms Brulé, Nez Percé, and Vieux Désert; of the letter $i$ with acute for Cochití of the ligature oe and the letter $e$ with grave for Cour d'Alène; and of the letter $n$ with tilde for Mimbreño and Zuñi. The 1900 Office of Indian Affairs list exhibited an additional footnote - "Hopi is the proper tribal name, Moki being an opprobrious nickname" - as a proviso for the Hopi and the Moki, see Hopi entries (Annual reports of the Department of the Interior for the fiscal year ended June 30, 1900, 1900a, p. 519). ${ }^{12}$

Further, there was a very real expectation that the employment of this list would follow its publication. The Commissioner requested that "[h]ereafter in annual reports and other official correspondence employees of this Bureau will please follow closely the spelling of Indian names as herewith given" (Rules and regulations, 1907, p. 161). Thus, Indian names were to be treated exactly as those geographic names determined by the Geographic Board: they were "to be accepted by these [executive] departments as the standard authority for such matters," as described in President Harrison's Executive Order in 1890 (Sixth Report of the United States Geographic Board, 1933, p. v). Table 1 presents this array of 270 tribe names, reproduced from the Annual Report of the Commissioner of Indian Affairs for 1900 (Annual reports of the Department of the Interior for the fiscal year ended June 30, 1900, 1900a, p. 519).

\section{The Government Printing Office's Manual of Style}

Unfortunately, even though the Government Printing Office had initiated the development of a standardized spelling list for tribe names, as declared by Commissioner Jones in his report for 1900 (Annual reports of the Department of the Interior for the fiscal year ended June 30, 1900, 1900a, p. 51), the Manual of Style Governing Composition and Proof Reading failed to include all those names provided by the Office of Indian Affairs. Instead, just 233 of the 270 of these were published (Manual of Style Governing Composition and Proof Reading in the Government Printing Office Together with Decisions of the Board on Geographic Names, 1900, p. 64). Those 37 tribe names deleted from the "Names of Indian tribes and bands" list for republication in the Manual of Style - e.g., Cahulia, see Kawia - are underlined in Table 1. The text of the HopiMoki footnote was attenuated to read "Hopi is the proper tribal name, Moki being a nickname," but spellings for Brulé, Nez Percé, Vieux Désert, Cochití, Cour d'Alène, Mimbreño, and Zuñi designations were maintained as initially presented by the Indian Office. In comparison, and promptly following this tribe register, the parallel collection of geographic benchmarks, conveyed in a roll of "Decisions of Board of Geographic Names," displaced almost 130 pages of this guide. The inventory was reproduced in 1903 (Manual of Style for Use in Composition and Proof Reading, 1903, p. 64), and again in 1904 (Manual of Style for Use in Composition and Proof Reading, 1904, p. 64), but both had removed the Hopi-Moki remark by that time.

11. An earlier bill for the same purpose, submitted by Senator James Donald Cameron (R-PA) in January 1880, had had the correct standardized spelling versions for each term (Journal of the Senate, 1880, p. 135).

12. John P. Harrington, a linguist at the Bureau of American Ethnology during the first half of the twentieth century (Judd, 1967, pp. 46-47), wrote his Note on the names Moqui and Hopi (1945, p. 177) that postulated that Moqui (more precisely, Moqüi) was the original name and that the designation of the tribe was changed to Hopi because "the name Moqui sounds like the word meaning "dead" [i.e., móki] in the Hopi language and is therefore obnoxious to the natives." See Connelly (1979, p. 551) for a more complete discussion of the two terms. The English version of móki led to the term Moki used by the Office of Indian Affairs for their "Names" list. 


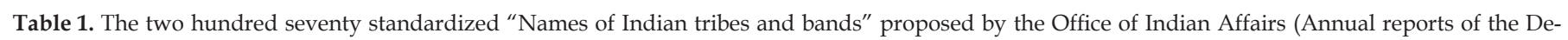

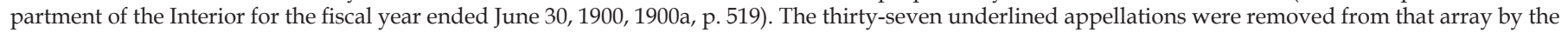

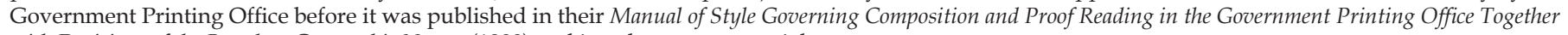
with Decisions of the Board on Geographic Names (1900) and in subsequent materials.

\begin{tabular}{|c|c|c|c|}
\hline Absaroka, see Crow & Hoopa, see Hupa & Natchez & Sichumovi (Hopi village) \\
\hline Acoma & Hopi & Navaho & Siletz \\
\hline Aionai & Hualapai, see Walapai & Nespelim & Sioux \\
\hline Algonkin (tribe) & Humptulip & Nestucca & Sisseton \\
\hline Algonquian (stock) & Hunkpapa & Nez Percé (pl. Nez Percés) & Sixes, see Kwatami \\
\hline Alsea & Hupa & Nisqualli & Sklallam \\
\hline Anadarko & Huron, see Wyandot & Nomelaki & Skokomish \\
\hline Apache & Ioni, see Aionai & Nooksak & Spokan \\
\hline Arapaho & Iowa & Oglala & Squaxon \\
\hline Arikara & Iroquois & Ojibwa, see Chippewa & Stockbridge \\
\hline Assiniboin & Isleta & Okinagan & Supai, see Havasupai \\
\hline Bannock & Jemez & Omaha & Swinomish \\
\hline Blackfoot (pl. Blackfeet) & Jicarilla & Oneida & Tabaquache \\
\hline Blood (pl. Bloods) & Joshua & Onondaga & $\overline{\text { Taos }}$ \\
\hline Bois Fort Chippewa & Kaibab & Oraibi (Hopi village) & Tenino \\
\hline Brulé & Kalapuya & Osage & Tesuque \\
\hline Caddo & Kalispel & Oto & Teton \\
\hline Cahuila, see Kawia & Kansa & Ottawa & Tillamook \\
\hline Calapooya, see Kalapuya & Kaskaskia & Ozette & Tonawanda \\
\hline Calispel, see Kalispel & Kaw, see Kansa & Paguate (Laguna village) & Tonkawa \\
\hline Capote & Kaweah, see Kawia & Paiute & Tonto Apache \\
\hline Cayuga & Kawia & Paloos & Tootootna, see Tututni \\
\hline Cayuse & Kickapoo & $\overline{\text { Panaca }}$ & Towakoni \\
\hline Chastacosta & Kiowa & Papago & Tukuarika ("Sheepeater") \\
\hline Chehalis & Klamath & Paraje (Laguana village) & Tulalip \\
\hline Chemehuevi & Klikitat & Paviotso & Tuscarora \\
\hline Cherokee & Kootenai, see Kutenai & Pawnee & Tututni \\
\hline Chetco & Kuteani & Pend d'Oreille & Uchee, see Yuchi \\
\hline Cheyenne & Kwapa, see Quapaw & Pennacook & Uinta \\
\hline Chickasaw & Kwatami & Peoria & Ukie, see Yuki \\
\hline Chilkat & Lac Courte Oreille & Piankashaw & Umatilla \\
\hline Chinook & Laguna & $\underline{\text { Picuris }}$ & Umpqua \\
\hline Chippewa & Lake Indians & Piegan & Uncompahgre \\
\hline Chiricahua & Lakmiut & Pima & Unkpapa, see Hunkpapa \\
\hline Chocktaw & L'Anse & Pisquow & Ute \\
\hline Clackamas (singular and plural) & Lipan & Pit River Indians & Vieux Désert, Chippewa \\
\hline Clallam & Luckamute, see Lakmiut & Pojoaque & Waco \\
\hline Clatsop & Lummi & Polacco, see Polakakai & Wahpeton \\
\hline Clickatat, see Klikitat & Mac qua noot na, see Mikonotuni & Polakakai & Wailaki \\
\hline Coahuila, see Kawia & Mahican & Ponca & Walapai \\
\hline Cochití & Makah & Potawatomi & Wallawalla \\
\hline Coconino, see Havasupai & Mandan & Pueblo & Walpi (Hopi village) \\
\hline Cocopa & Maricopa & Puyallup & Wasco \\
\hline Cœur d'Alène & Mdewakanton & Quaitso & Washaki \\
\hline Colville & Menominee & Quapaw & $\underline{\text { Washo }}$ \\
\hline Comanche & Mescalero & Queet, see Quaitso & Wazhazhe \\
\hline Concow & Methow & Quileute & Wea \\
\hline Coos & Miami & Quinaielt & Wenatchi \\
\hline Coquille & Mikonotuni & Ree, see Arikara & Wichita \\
\hline Cowlitz & Mimbreño & Sac, see Sauk & Wichumni \\
\hline Coyotero & Miniconjou & Salish & Wiminuche \\
\hline Cree & Minitaree, see Hidatsa & Sandia & Winibigoshish \\
\hline Creek, or Muskogee (pl. Creeks) & Mishongnovi (Hopi village) & Sanpoil & Winnebago \\
\hline Crow (pl. Crows) & Missouri & Sans Arcs (sing. and pl.) & Wyandot \\
\hline Dakota & Moache & Santee & Wylacki, see Wailaki \\
\hline Delaware (pl. Delawares) & Modoc & Santiam & Yakima \\
\hline Dwamish & Mogollon & Sauk & Yankton \\
\hline Euchee, see Yuchi & Mohave & Seminole & Yanktonai \\
\hline Flathead (pl. Flatheads) & Mohawk & Seneca & Yaqui \\
\hline Fox (pl. Foxes) & Mohican, see Mahican & Shawnee & Yaquina \\
\hline Gila Apache & Moki, see Hopi & Shebit, see Shivwits & Yava Supai, see Havasupai \\
\hline Goship & Molala & Sheepeater, see Tukuarika & Yavapai \\
\hline Gosiute & Montauk & Shipaulovi (Hopi village) & Yuchi \\
\hline Grosventre (pl. Grosventres) & Moqui, see Hopi & Shivwits & Yuki \\
\hline Hano (Hopi village) & Muckleshoot & Shoshoni & Yuma \\
\hline Havasupai & Munsee & Shumopovi (Hopi village) & Zia, see Sia \\
\hline Hidatsa & Muskogee (or Creek) & Sia & Zuñi \\
\hline Hoh & Nambe & & \\
\hline
\end{tabular}

2. Charles J. Kappler's Indian Affairs: Laws and Treaties,
1903-1904

It was clear that Commissioner of Indian Affairs Jones had an additional reason to be interested in a standardized list of tribe names. He proposed in 1899 and 1900 a new, up to date collection of federal Indian legal materials. In a portion of his 1900 Annual Report entitled "Needed Publication on Indian Matters," he stated that a previous compilation was "inaccurate" and that "[t]he demand for a publication that shall contain all ratified treaties and agreements made by the United States with the Indian tribes is increasing. It would be in constant use in this office and would be 
frequently referred to by other Government bureaus and by members of Congress as well as by the public at large" (Annual reports of the Department of the Interior for the fiscal year ended June 30, 1900, 1900a, p. 50). This request was repeated for a third time in the 1901 Annual Report (Annual reports of the Department of the Interior for the fiscal year ended June 30, 1901, 1901, pp. 46-47).

In response, the Senate authorized Charles J. Kappler, as Clerk for the Senate Committee on Indian Affairs, to collect these important yet dispersed materials. The first two volumes were published in 1903, as successive Serial Set items. Volume 1 housed "Statutes, executive orders, proclamations, and statistics of tribes" and volume 2 consisted of the final texts of the recognized treaties (Kappler, 1903a, 1903b). The following year, the same materials were republished in another pair of Serial Set tomes, with adjustments to their formats (Kappler, 1904a, 1904b). Kappler noted in the preface to the second edition (1904a, p. v) that " $\mathrm{t}]$ he new edition has afforded the compiler an opportunity to make such typographical and other corrections as were discovered in the first print, to insert several treaties and documents which were heretofore unobtainable, and to add the signatures subscribed to each treaty which was omitted in the first edition to save space."13

Kappler's preface, identical in both the 1903 and 1904 editions of the first volume of Indian Affairs, indicated that "[a]t the suggestion of the Commissioner of Indian Affairs, the correct modern spelling of Indian names, as decided by the Indian Office and the Bureau of Ethnology, has been introduced and adopted in the headlines to the treaties, but in the text it was found expedient to follow the orthography of the Statutes" (1903a, p. iii). His version of Interior's "Names of Indian tribes and bands" was entitled "Revised spelling of names of Indian tribes and bands;" it was placed in Appendix I (1903a and 1904a, p. 1021). It is important to note that he apparently added one more tribe to this identifier collection. In between the original Sac, see Sauk and Salish entries, Kappler placed Saint Regis, i.e., the Mohawk group named for the site established in the 1740s in the northwestern corner of New York, and participants in two treaties: the Treaty with the Seven Nations of Canada, 1796 and the Treaty with the New York Indians, 1838 (Kappler, 1904b, pp. 45-46 and 502-516, respectively). ${ }^{14}$ His 1903 and 1904 collections thus had revised spellings for a total of 271 entries.

These modifications were employed by Kappler to standardize tribal names in the titles of each treaty transaction, but as a conscientious attorney, he adhered to their final texts located in the Statutes at Large. ${ }^{15}$ The abundant Index in the Treaties volume was populated by tribes under their new names. This link then, beginning with the original request by the Government Printing Office to the Indian Office for an ensemble of standardized tribal spellings, and the subsequent call by the Commissioner of Indian Affairs to make use of such a list in a new Congressionally-approved compilation of materials related to American Indian law, paralleled the geographic name endeavors to create a consistent body of knowledge.

\section{Applications of the "Names of Indian tribes and bands"}

The tribal spellings initially found by Kappler in the treaty texts within the Statutes at Large were an ample demonstration of the overall problem - negotiators in the field and printers in Washington had a variety of orthographies with which to identify these groups. As just one example, a lexicon of the recognized treaties with the tribes revealed that the Potawatomi had their name spelled over a dozen ways in treaty documents, commencing with the Treaty with the Wyandot, etc., 1789 (Kappler, 1904b, pp. 18-23; 7 Stat. 28) in which they were identified as both the Pattawatima and the Pattiwatima. ${ }^{16}$ This tribe has had a diverse history, beginning it is thought in the lower peninsula of Michigan, and recognized under many titles (Hodge, 1906b, pp. 289-293; Swanton, 1952, pp. 247-250; Clifton, 1978; Edmunds, 1978). The proposed 1900 spelling Potawatomi is maintained today by the Citizen Potawatomi Nation, Oklahoma; the Forest County Potawatomi Community, Wisconsin; the Nottawaseppi Huron Band of the Potawatomi, Michigan; the Pokagon Band of Potawatomi Indians, Michigan and Indiana; and the Prairie Band of Potawatomi Nation, Kansas. These names - and their spellings - appear on the latest list of Indian entities recognized by the Bureau of Indian Affairs (2009, pp. 40219-40221). ${ }^{17}$ In the same document, the identities of eleven of the seventeen recognized Pueblos (p. 40221) are consistent with those itemized in the 1900 collation and - absent the five Pueblos of San Felipe, San Ildefonso, Santa Ana, Santa Clara, and Santo Domingo that do not appear on the original inventory - only the name of the Pueblo of Cochiti differs from the earlier proposed accented Cochití term.

Virtually simultaneous with Kappler's efforts to construct the first volumes of Indian Affairs, the Government Printing Office chose to limit the provided name list for their Manual of Style, by removing thirty-seven suggestions from the initial listing. These absentees included six of the seven previous Hopi village identifiers, and one of the two Laguna ones. Only Shipaulovi of the Second or Middle Mesa and Paguate, respectively, remained. Connelly (1979, p. 552; see the map on p. 539) indicated that the former - the 'place of the mosquitoes' - was renamed, but that "the spelling Shipolovi, adopted in 1915 by the U.S. Board on Geographic Names, has generally not been used (except on government maps) because it reflects an incorrect pronunciation." 18 Ellis (1978, p. 438) furnished a map of the Laguna Pueblo, with Paguate in the north, and a photograph entitled "Winnowing wheat at Paguate, one of Laguna's outlying farm villages" (p. 442). Seven directives to other names were removed; all but one of these preferred alternative names were retained, with Aionai and Ioni, see Aionai as the sole eliminated pair. ${ }^{19}$ The list of Pueblos was decimated - putting aside the removal of the Zia, see Sia directive, the names Isleta, Nambe, Picuris, Pojoaque, Sandia, Taos, and Tesuque were eliminated from the Manual of Style's assortment.

Thus, absent a few groups such as the Apache, many of the eliminated names had identified relatively small entities. Two such culled examples - the Paloos and Pisquow - may be found along with others in the preamble to the Treaty with the Yakima, 1855 (Kappler, 1904b, pp. 698-702) and "who for the purposes of this treaty are to be considered as one nation, under the name of 'Yakama.'” In the instrument's text in the Statutes at Large (12 Stat. 951), the names appear as Palouse and Pisquouse; see Sprague (1998), who used the same spelling for the former. The Tabaquache band of Ute Indians

13. Three later volumes appeared (Kappler, 1913, 1929, 1941), and then publishers other than the federal government created versions of these collations, including stand-alone publications of volume 2 (Kappler, 1972a, 1973) and a new set of all five volumes (Kappler, 1972b).

14. Fenton and Tooker (1978, p. 469) have more on the development of the Saint Lawrence settlements, including a map of the Saint Regis Reserve (p. 471). 15. See more on Kappler and his achievements in Bernholz and Weiner (2008).

16. Bernholz, Pytlik Zillig, and Anderson (2008) constructed a lexicon for all 375 recognized treaties with American Indians.

17. Note too that older spellings prevail: Pottawatomie County in Kansas and Oklahoma, and Pottawattamie County in Iowa. The latter's Web page declares: "Pottawattamie County was a part of the Pottawattamie Purchase of 1847 . The county was originally named after the Native American tribe that once existed and lived within the Iowa Territory. Pottawattamie is a traditional word meaning "Fire Keepers" or "Keepers of the Council Fires"" (see http://www.pottcounty.com/). The so-called Purchase was part of the Treaty with the Potawatomi Nation, 1846 (Kappler, 1904b, pp. 557-560). In the preparation of this specific instrument for his collation, Kappler's adherence to "Names of Indian tribes and bands" was sustained: the title of the document in the Statutes at Large is the Treaty with the Pottowautomie Nation. The inconsistency was not unnoticed - a footnote on the initial Statutes page remarked that "The name of this tribe is, in different treaties, spelled very differently" (9 Stat. 853).

18. The entry for the new spelling Shipolovi in the Sixth Report of the United States Geographic Board: 1890 to 1932 (1933, p. 689$)$ denotes "Shipolovi: settlement, Hopi Indian Reservation, Navajo County, Ariz. (Not Shi-pau-i-luvi, Shipaulovi, nor Shipowlawe)."

19. Three of these directives led to Kawia, and one each to Havasupai, Polakakai, and Sia. 
was the subject of the Treaty with the Utah - Tabeguache Band, 1863 (Kappler, 1904b, pp. 856-859), where their name was spelled with a $g$, not a $q$, in both the Statutes at Large (13 Stat. 673) and in Kappler's title for this document. Lands reserved in a later transaction, that had made early use of the 1900 standardized band name spelling (Treaty with the Ute, 1868, pp. 990-996), were modified by An act to ratify an agreement with certain Ute Indians in Colorado, and to make an appropriation for carrying out the same (18 Stat. 36 [1874). (Kappler, 1903a) and (Kappler, 1904a), p. 151), and his index used the first treaty's spelling for his "Tabeguache band of Ute, agreement of September 13, 1873, ratified" entry in a collection of "Permanent Acts Relative to Particular Tribes" of the first session of the fortythird Congress (p. 151; emphasis added). The act itself presented the later revised spelling of "the chiefs, headmen, and men of the Tabequache, Muache, Capote, Weeminuche, Yampa, Grand River, and Uintah bands of Ute Indians" (1903a and 1904a, p. 151; 18 Stat. 36, 37; emphasis added). Interestingly, the Statutes (15 Stat. 619) contain both spellings in the earlier Treaty with the Ute, 1868 transaction: Tabeguache is employed in the preamble, yet Tabequache appears in the articles and in the signature section. An italicized $q$, present in these latter cases, suggests that the Statutes text was adjusted prior to printing.

Nevertheless, and even with the Government Printing Office's decision to attenuate the full register, this new orthography prevailed in federal communications, and especially in the output of the Bureau of American Ethnology and of the Smithsonian Institution. A comparison between titles such as The Menomini Indians (Hoffman, 1896) and Menominee Music (Densmore, 1932) is an immediate indicator of this convergence to a standard suite of tribe names. Densmore cited Hoffman in his later work, but used the revised tribe spelling in his publication. Hoffman (pp. 12-13) had provided a synonymy that looked very much like the one that Hodge produced for the Menominee a decade later (1906a, pp. 843-844), thereby exposing the ongoing work in house at the Bureau that spilled over into, and was later revealed in, Hodge's epic work. Regardless of its current spelling, the term derives from the Ojibwa, and is the same in Algonquin and in other Algonquian languages: it means 'wild rice people' (Spindler, 1978, p. 723). The break from the old orthographic style - demonstrated by Hoffman's synonymy list - was made even clearer when Hodge's 1906 Handbook of American Indians north of Mexico promptly employed this new vocabulary. Half a century later, Swanton's important contribution, The Indian Tribes of North America (1952), displayed further the uses of the Indian Office glossary. This application of the "Names of Indian tribes and bands" list was sustained into the twenty-first century through the publication of volumes of the Handbook of North American Indians (1978-), under the editorship of William C. Sturtevant (see Merrill \& Goddard, 2002), who had begun his own career with a publication on traditional Seneca Indian musical instruments (Conklin \& Sturtevant, 1953). ${ }^{20}$

Later still, and in preparation for the bicentennial of the Lewis and Clark Expedition, Moulton (2001) fashioned an index for the contents of the Journals' almost 5000 pages. ${ }^{21}$ In the introduction to this resource, he spoke of the editorial comments added to supplement the original texts and he forewarned that "[a]ttention to the notes is essential to locating the party by modern place names, citing Indian nations by their modern denominations, and identifying species by their current popular and scientific names" (p. xi; em- phasis added). Thus, a bridge was formed between the old names of tribes - some of which were seen for the very first time by Lewis and Clark - and the so-called "modern denominations" for them to which the "Names of Indian tribes and bands" list had contributed. The index entries such as Arikara, Nez Percé, and Yaquina are links to appellation models acknowledged today, but which were not employed two centuries ago (pp. 3, 108, and 166, respectively). There remain, nonetheless, differences between Moulton's spellings and those from the 1900 Names compilation, driven in part by the endless evolution of the terms in such a catalog: Grosventre is now rendered as Gros Ventre, and the initial directive Minitaree, see Hidatsa would today appear as Moulton's Minitari cross-reference to Hidatsa (pp. 69 and 101, respectively).

Recently, Clark (2009) has created an extensive cross-referenced inventory of tribal names for all of the Americas. The fact that this catalog subtends almost 300 pages is another ample demonstration of the task faced by all compilers of these identities. Although the "Names of Indian tribes and bands" list was not cited, the array of names provides evidence of the continued development of, and the commitment to, such synonymies. The foundation of this ensemble was the 14th edition of the Library of Congress Subject Headings (1991), Hodge's Handbook of American Indians north of Mexico (1906a and b), and Swanton's The Indian Tribes of North America from 1952, supplemented by other publications like Kroeber's 1924 Handbook of the Indians of California (P. R. Clark, personal communication, 22 October 2009). ${ }^{22}$ The format was similar to Hodge's, with the use of directives that link to location and source codes for the main entry. For example, the entry Washee, see Washo leads to Washo [CA, NV] (LC) that in turn conveys the tribe's approximate location as California and Nevada, and that the spelling source for the name was the 14th edition of the Library of Congress Subject Headings (p. 282). ${ }^{23}$

The Washoe are a particularly relevant example of the evolution of such "standardized" names. In 1900, the Washo identifier appeared on the "Names of Indian tribes and bands" roll, but it was one of the terms excluded from those Government Printing Office style Manuals. The Bureau of American Ethnology continued to use the form in a number of their later fundamental publications (Hodge, 1906b, p. 920; Swanton, 1952, pp. 383-384). Later, though, it emerged as Washoe in a series of Indian Claims Commission proceedings (see, for example, Washoe Tribe v. United States, 1970); in d'Azevedo's article in the Handbook of North American Indians (1986); in the federal inventory of recognized groups (Indian entities recognized by the Bureau of Indian Affairs, 2009, p. 40222); and even on the tribe's website, posted under their official name, the Washoe Tribe of Nevada and California, that appears on that Indian entities recognized compilation (http:/ / www.washoetribe. us/). The variability of this prototype was described succinctly by d'Azevedo (1986, p. 497; emphasis added), who acknowledged that "[ $t$ ]he spelling Washo was established as standard for the anthropological and linguistic literature by Hodge" through his Handbook (see Hodge, 1906b, p. 920). D'Azevedo remarked that Kroeber had provided "Washoe as a variant" (see Kroeber, 1907, p. 252), yet had used Washo only in the tribe's chapter of his later Handbook of Indians of California (Kroeber, 1924, pp. 569-573). ${ }^{24}$ However, "[t]he spelling Washoe, which has generally prevailed locally and is used by the Washoe Tribe, has been adopted in the Handbook [of North American Indians]" (d'Azevedo, 1986, pp. 497-

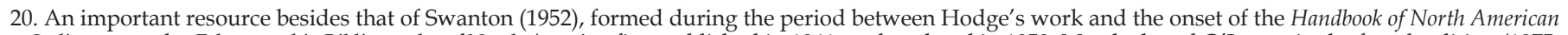
Indians, was the Ethnographic Bibliography of North America, first published in 1941, and updated in 1953. Murdock and O'Leary, in the fourth edition (1975, p. 425), declared that their expanded "ethnonymy... a list of names of ethnic groups, together with alternate names and variant spellings" had been based on that found in the earlier third version (Murdock, 1960). They advised, however, that Hodge's synonymy (1906b) "should be the first source to be consulted for information on any name which is not in the present ethnonymy."

21. See http:/ / lewisandclarkjournals.unl.edu/ for the entire Journals of the Lewis and Clark Expedition collection.

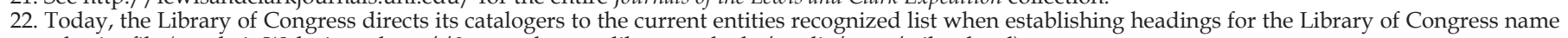
authority file (see their Web site at http:/ / -www.loc.gov.library.unl.edu/catdir/cpso/tribes.html).

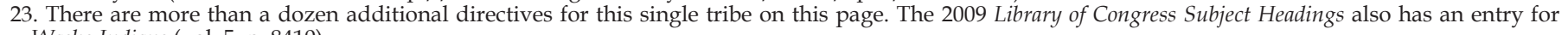
Washo Indians (vol. 5, p. 8410).

24. Hodge had cited Kroeber's work on the Washo, which was published in 1907. 
498), thereby recognizing the tribe's own preference, even at the expense of departing from the federal government's 1900 effort to normalize their name. ${ }^{25}$

\section{Conclusions}

It is clear that a parallel set of policies was in place at the end of the nineteenth century that pertained to the standardization of ethnologic and geographic terms. The United States Board on Geographic Names had shown concern for the "utmost confusion [that] exists regarding geographic names" (1892, p. 4), and Commissioner of Indian Affairs Jones had in tandem echoed these very sentiments when it came to the diversity of names for American Indians. These efforts to generate standard forms for these diverse terms were fruitful. The consistency of today's tribe and band names, as well as of geographic terms, is very much reflected in the current version of the 564 Indian entities recognized and eligible to receive services from the United States Bureau of Indian Affairs (2009) that includes more than 220 Alaska Native groups. ${ }^{26}$

The overall federal policy to coordinate consistent labels for the nation's geographic assets was paralleled by the challenge to do the same for American Indians spread throughout the same universe; it was an issue for the government of understanding where, as well as whom. Those earlier arrays of sometimes wildly disparate tribe names still pervaded any historical inquiry and required then, as they do today, the consideration that they were operational at the time that they were employed in documents. The "Names of Indian tribes and bands" was the Indian Office's contribution to this new national endeavor, a small step made in conjunction with the Bureau of American Ethnology towards a better understanding of their names, that fundamental characteristic that John Wesley Powell realized "underlies and is the foundation for every field of ethnographic investigation among Indians." This collection of 270 names; its later distribution to federal employees by the Government Printing Office; and the relatively consistent use of its terms to identify tribes and bands, in such important contemporary resources as the Handbook of North American Indians, have helped expedite such essential ethnographic endeavors over the last century, in ways that circumvented the previously impeding "maze of nomenclatural perplexity."

\section{Acknowledgments}

Several colleagues examined their collections to expedite this investigation. I thank Michael Abramson (United States Government Printing Office), Marie Concannon (University of Missouri-Columbia), Edward Herman (SUNY Buffalo), Julie Linden (Yale University), and Carmen Orth-Alfie (University of Kansas) for their help.

\section{References}

Abler and Tooker, $1978 \varangle$ T. S. Abler \& E. Tooker, Seneca. In W. C. Sturtevant \& B. G. Trigger (eds.). Handbook of North American Indians, vol. 15: Northeast (pp. 505-517). Washington, DC: Smithsonian Institution, 1978.

Annual report of the Board of Regents of the Smithsonian Institution, 18984 Annual report of the Board of Regents of the Smithsonian Institution showing the operations, expenditures, and condition of the Institution to July 1896. (1898). House of Representatives. 54th Congress, 2nd session. House Document No. 352, part 1 (Serial Set 3548). Washington, DC: Government Printing Office.

Annual reports of the Department of the Interior for the fiscal year ended June 30, 1900, 1900a Annual reports of the Department of the Interior for the fiscal year ended June 30, 1900. Indian Affairs. Report of the Commissioner and appendixes. (1900a). House of Representatives. 56th Congress, 2nd session. House Documen No. 5, part 2. 1 (Serial Set 4101). Washington, DC: Government Printing Office.

Annual reports of the Department of the Interior for the fiscal year ended June 30 $1900,1900 \mathrm{~b}$ Annual reports of the Department of the Interior for the fiscal year ended June 30, 1900. Indian Affairs. Commission to the Five Civilized Tribes. Indian Inspector for Indian Territory. Indian contracts. Board of Indian Commissioners. (1900b). House of Representatives. 56th Congress, 2nd session. House Document No. 5, part 2. 2 (Serial Set 4102). Washington, DC: Government Printing Office.

Annual reports of the Department of the Interior for the fiscal year ended June 30 1901, 1901 Annual reports of the Department of the Interior for the fiscal year ended June 30, 1901. Indian Affairs. Part I. Report of the Commissioner, and appendixes. (1901). House of Representatives. 57th Congress, 1st session. House Document No. 5, part 2-1 (Serial Set 4290). Washington, DC: Government Printing Office.

Baird, 1979 W. D. Baird, William A. Jones, 1897-1904. In: R. M. Kvasnicka and H. J. Viola, eds., The Commissioners of Indian Affairs, 1824-1977, Lincoln, NE, University of Nebraska Press (1979), pp. 211-220.

Bernholz and Weiner, 20084 C. D. Bernholz and R. J. Weiner, The world of Charles J. Kappler: A digital portrait, Legal Reference Services Quarterly 27 (2008), pp. 377-383.

Bernholz et al., 2008 C. D. Bernholz, B. L. Pytlik Zillig, and C. G. Anderson, The words you brought us: Digital lexicon of the recognized American Indian treaties, Library Collections, Acquisitions, and Technical Services 32 (2008), pp. 104-106.

Campisi, $1978 \varangle$ J. Campisi, Oneida. In W. C. Sturtevant \& B. G. Trigger (eds.). Handbook of North American Indians, vol. 15: Northeast (pp. 481-490). Washington, DC: Smithsonian Institution, 1978.

Clark, 20094 P. R. Clark, Tribal names of the Americas: Spelling variants and alternative forms, cross-referenced, McFarland, Jefferson, NC, 2009.

Clifton, $1978<$ J. A. Clifton, Potawatomi. In W. C. Sturtevant \& B. G. Trigger (eds.) Handbook of North American Indians, vol. 15: Northeast (pp. 725-742). Washington, DC: Smithsonian Institution, 1978

Conklin and Sturtevant, $1953 \varangle$ H. C. Conklin and W. C. Sturtevant, Seneca Indian singing tools at Coldspring Longhouse: Musical instruments of the modern Iroquois, Proceedings of the American Philosophical Society 97 (1953), pp. 262-290.

Connelly, $1978 \varangle$ J. C. Connelly, Hopi social organization. In W. C. Sturtevant \& A Ortiz (eds.). Handbook of North American Indians, vol. 9: Southwest (pp. 539-553). Washington, DC: Smithsonian Institution, 1978

d'Azevedo, 19864 W. L. d'Azevedo, Washoe. In W. C. Sturtevant \& W. L. d'Azevedo (eds.). Handbook of North American Indians, vol. 11: Great Basin (pp. 466-498). Washington, DC: Smithsonian Institution, 1986.

DeMallie, $2001<$ R. J. DeMallie, Sioux until 1850. In W. C. Sturtevant \& R. J. DeMallie (eds.). Handbook of North American Indians, vol. 13, part 2: Plains (pp. 718-760). Washington, DC: Smithsonian Institution, 2001

Densmore, 1932 F. Densmore, Menominee music. House of Representatives. 71st Congress, 3rd session. House Document No. 817 (Serial Set 9473). Washington, DC: Government Printing Office, 1932.

Edmunds, $1978 \varangle$ R. D. Edmunds, The Potawatomis: Keepers of the fire, University of Oklahoma Press, Norman, OK (1978).

Ellis, $1978<$ F. H. Ellis, Laguna Pueblo. In: W. C. Sturtevant and A. Ortiz, eds., Handbook of North American Indians, Southwest 9, Smithsonian Institution, Washington, DC (1978), pp. 438-449.

Fenton and Tooker, $1978 \leftarrow$ W. N. Fenton \& E. Tooker, Mohawk. In W. C. Sturtevant \& B. G. Trigger (eds.). Handbook of North American Indians, vol. 15: Northeast (pp. 466-480). Washington, DC: Smithsonian Institution, 1978.

Fifth Report of the United States Geographic Board: 1890 to 1920, 1921 Fifth Report of the United States Geographic Board: 1890 to 1920. (1921). Washington, DC: Government Printing Office.

Fourth Report of the United States Geographic Board: 1890 to, 1916 Fourth Report of the United States Geographic Board: 1890 to 1916. (1916). Washington, DC: Government Printing Office.

Harrington, $19454 \mathrm{~J}$. P. Harrington, Note on the names Moqui and Hopi. American Anthropologist 47 (New Series) (1945), 177-178.

Hodge, 1906a F. W. Hodge, Handbook of American Indians north of Mexico. House of Representatives. 59th Congress, 1st session. House Document No. 926, part 1 (Serial Set 5001). Washington, DC: Government Printing Office, 1906.

Hodge, 1906b 4 F. W. Hodge, Handbook of American Indians north of Mexico. House of Representatives. 59th Congress, 1st session. House Document No. 926, part 2 (Serial Set 5002). Washington, DC: Government Printing Office, 1906.

Hoffman, 18964 W. J. Hoffman, The Menomini Indians. In Fourteenth annual report of the Bureau of Ethnology to the Secretary of the Smithsonian Institution 1892-93 (pp. 11328). House of Representatives. 54th Congress, 2nd session. House Document No. 230, part 1 (Serial Set 3531-1). Washington, DC: Government Printing Office, 1896.

Indian entities recognized and eligible to receive services from the United States Bureau of Indian Affairs, 2009 Indian entities recognized and eligible to re-

25. As two further illustrations of this variation, Mithun (1999, p. 557) described the contact made with the Washo, beginning with John Fremont in 1844, who allegedly made note of "the first two Washo words." The section begins with a heading that states "Washo = Washoe," but Washo is used elsewhere throughout her publication. See also Yu's (2008, p. 508) "quantitative analysis of the complementary length alternation between tonic vowels and posttonic consonants in two generations of speakers of Washo, a severely moribund Hokan language spoken by approximately 13 elderly speakers near the California-Nevada border southeast of Lake Tahoe." He too observed that the name may be spelled as Washoe (p. 509). The article appeared in a special issue of the Journal of Phonetics devoted to "Phonetic Studies of North American Indigenous Languages."

26. The very names of the latter societies mirror the "decisions concerning several hundred names in Alaska" that the first report of the United States Board on Geographic Names (1892, p. 4) characterized over a century ago. These standardized names exist now, from the Native Village of Akutan ("Akutan: village, on the north shore of Akutan Harbor, Akutan Island, eastern Aleutians, Alaska" - Sixth Report of the United States Geographic Board, 1933, p. 84) to the Wrangell Cooperative Association ("Wrangell: town, on western side of northern end of Wrangell Island, lat. $56^{\circ} 28^{\prime} .3$ N., long. $132^{\circ} 23^{\prime} .1$ W., southeastern Alaska. (Not Fort Wrangel or Wrangle)" - p. 825). 
ceive services from the United States Bureau of Indian Affairs, Federal Register 74 (153) (2009), pp. 40218-40223.

Journal of the Senate of the United States of America, being the session specially called Monday, October 10, 1881 Journal of the Senate of the United States of America, being the session specially called Monday, October 10, 1881, and the first session of the Forty-seventh Congress; begun and held at the City of Washington, December 5, 1881, in the one hundred and sixth year of the independence of the United States. (1881). Senate. 47th Congress, 1st session and 47th Congress, Special Senate Session 2 (Serial Set 1984). Washington, DC: Government Printing Office.

Judd, $1967 \varangle$ N. M. Judd, The Bureau of American Ethnology: A partial history, University of Oklahoma Press, Norman, OK (1967).

Kappler, 1903a \ Kappler, C. J. (1903a). Indian affairs. Laws and treaties, vol. 1. Statutes, executive orders, proclamations, and statistics of tribes. Senate. 57th Congress, 1st session. Senate Document No. 452, part 1 (Serial Set 4253). Washington, DC: Government Printing Office, 1903.

Kappler, 1903b 4 C. J. Kappler, Indian affairs. Laws and treaties, vol. 2. Treaties. Senate. 57th Congress, 1st session. Senate Document No. 452, part 2 (Serial Set 4254). Washington, DC: Government Printing Office, 1903.

Kappler, 1904a 4 C. J. Kappler, Indian affairs. Laws and treaties, vol. 1. Laws. Senate. 58th Congress, 2nd session. Senate Document No. 319, part 1 (Serial Set 4623). Washington, DC: Government Printing Office, 1904.

Kappler, 1904b $\varangle$ C. J. Kappler, Indian affairs. Laws and treaties, vol. 2. Treaties. Senate. 58th Congress, 2nd session. Senate Document No. 319, part 2 (Serial Set 4624). Washington, DC: Government Printing Office, 1904.

Kappler, $1913-$ C. J. Kappler, Indian affairs. Laws and treaties, vol. 3. Laws. Senate. 62nd Congress, 2nd session. Senate Document No. 719 (Serial Set 6166). Washington, DC: Government Printing Office, 1913.

Kappler, 1929 C. J. Kappler, Indian affairs. Laws and treaties, vol. 4. Laws. Senate. 70th Congress, 1st session. Senate Document No. 53 (Serial Set 8849). Washington, DC: Government Printing Office, 1929.

Kappler, 19414 C. J. Kappler, Indian affairs. Laws and treaties, vol. 5. Laws. Senate. 76th Congress, 3rd session. Senate Document No. 194 (Serial Set 10458). Washington, DC: Government Printing Office, 1941.

Kappler, 1972a \ C. J. Kappler, Indian Treaties: 1778-1883, Amereon House, Mattituck, NY (1972).

Kappler, 1972b C. J. Kappler, Indian Affairs: Laws and Treaties vol. 1-5, AMS Press, New York (1972).

Kappler, 1973 C. J. Kappler, Indian Treaties: 1778-1883, Interland Publishing, New York (1973).

Kroeber, 1907 A. L. Kroeber, The Washo language of east central California and Nevada, University of California Publications in American Archaeology and Ethnology 4 (1907), pp. 251-317.

Kroeber, 1924 A. L. Kroeber, Handbook of the Indians of California. House of Representatives. 68th Congress, 1st session. House Document No. 3 (Serial Set 8379). Washington, DC: Government Printing Office, 1924.

Lambert, $1978 \triangleleft$ M. F. Lambert, Pojoaque Pueblo. In W. C. Sturtevant \& A. Ortiz (eds.). Handbook of North American Indians, vol. 9: Southwest (pp. 324-329). Washington, DC: Smithsonian Institution, 1979.

Library of Congress Subject Headings, 1991 Library of Congress Subject Headings (14th ed.). (1991). Washington, DC: Library of Congress.

Library of Congress Subject Headings, 2009 Library of Congress Subject Headings (31st ed.). (2009). Washington, DC: Library of Congress.

List of Publications of the Bureau of American Ethnology, with Index to Authors and Titles, 19714 List of Publications of the Bureau of American Ethnology, with Index to Authors and Titles. (1971). Washington, DC: Smithsonian Institute.

Manual of Style for Use in Composition and Proof Reading, 1903 Manual of Style for Use in Composition and Proof Reading. (1903). Washington, DC: Government Printing Office.

Manual of Style for Use in Composition and Proof Reading, $1904 \varangle$ Manual of Style for Use in Composition and Proof Reading. (1904). Washington, DC: Government Printing Office.

Manual of Style Governing Composition and Proof Reading in the Government Printing Office Together with Decisions of the Board on Geographic Names, $1900-$ Manual of Style Governing Composition and Proof Reading in the Government Printing Office Together with Decisions of the Board on Geographic Names. (1900). Washington, DC: Government Printing Office.

Merrill and Goddard, $2002 \varangle$ W. L. Merrill and I. Goddard, Anthropology, history, and American history: Essays in honor of William Curtis Sturtevant, Smithsonian Institution, Washington, DC (2002).

Mithun, $19994 \mathrm{M}$. Mithun, The languages of native North America, Cambridge University Press, New York (1999).

Mooney, $1897 \varangle$ J. Mooney, Calendar history of the Kiowa Indians. In Seventeenth annual report of the Bureau of American Ethnology to the Secretary of the Smithsonian Institution 1895-96 (pp. 141-444). House of Representatives. 55th Congress, 3rd session. House Document No. 316, part 1 (Serial Set 3836). Washington, DC: Government Printing Office, 1897.

Moses, 19844 L. G. Moses, The Indian man: A biography of James Mooney, University of Nebraska Press, Lincoln, NE (1984).

Moulton, 20014 G. E. Moulton, The definitive journals of Lewis \& Clark: Comprehensive index, University of Nebraska Press, Lincoln, NE (2001).

Murdock, 1960 G. P. Murdock, Ethnographic bibliography of North America (3rd ed.), Human Relations Area Files, New Haven, CT (1960).

Murdock and O'Leary, 1975 G. P. Murdock, \& T. J. O'Leary, Ethnographic Bibliography of North America. Volume 1: General North America (4th ed.). New Haven, CT: Human Relations Area Files, 1975.

Opler, 19834 M. E. Opler, Mescalero Apache. In W. C. Sturtevant \& A. Ortiz (eds.).
Handbook of North American Indians, vol. 10: Southwest (pp. 419-439). Washington, DC: Smithsonian Institution, 1983.

Palmer, 1998 G. B. Palmer, Coeur d'Alene. In W. C. Sturtevant \& D. E. Walker (eds.) Handbook of North American Indians, vol. 12: Plateau (pp. 313-326). Washington, DC: Smithsonian Institution, 1998

Promoting uniformity of geographic nomenclature in the federal government, 1947 4 Promoting uniformity of geographic nomenclature in the federal government. (1947). House of Representatives. 80th Congress, 1st session. House Report No. 366. (Serial Set 11119). Washington, DC: Government Printing Office.

Powell, $1892 \varangle$ J. W. Powell, Indian linguistic families of America north of Mexico. In Seventh annual report of the Bureau of Ethnology to the Secretary of the Smithsonian Institution 1885-86 (pp. 7-142). House of Representatives. 52nd Congress, 1st session. House Miscellaneous Document No. 107 (Serial Set 2989). Washington, DC: Government Printing Office, 1892.

Randall, 19904 R. R. Randall, United States Board on Geographic Names: An agency established by law to serve the U. S. government and the public. Reston, VA: The Board, 1990.

Rules and regulations governing the Department of the Interior in its various branches, 1907 Rules and regulations governing the Department of the Interior in its various branches. (1907). Senate. 59th Congress, 2nd session. Senate Document No. 396, part 4. (Serial Set 5088). Washington, DC: Government Printing Office.

Second report of the United States Board on Geographic Names: 1890 to 1899. (1900) 4 Second report of the United States Board on Geographic Names: 1890 to 1899 (1900). House of Representatives. 56th Congress, 1st session. House Document No. 472 (Serial Set 3988). Washington, DC: Government Printing Office.

Seventh annual report of the Bureau of Ethnology to the Secretary of the Smithsonian Institution 1885-'86, 18924 Seventh annual report of the Bureau of Ethnology to the Secretary of the Smithsonian Institution 1885-86. (1892). House of Representatives. 52nd Congress, 1st session. House Miscellaneous Document No. 107 (Serial Set 2989). Washington, DC: Government Printing Office.

Shaul, 19994 D. L. Shaul, Linguistic natural history: John Wesley Powell and the classification of American languages, Journal of the Southwest 41 (1999), pp. 297-310.

Sixteenth annual report of the Bureau of American Ethnology to the Secretary of the Smithsonian Institution 1894-'95, 1897 Sixteenth annual report of the Bureau of American Ethnology to the Secretary of the Smithsonian Institution 189495. (1897). House of Representatives. 55th Congress, 1st session. House Document No. 93 (Serial Set 3580). Washington, DC: Government Printing Office.

Sixth Report of the United States Geographic Board: 1890 to, $1932 \varangle$ Sixth Report of the United States Geographic Board: 1890 to 1932, Sixth Report of the United States Geographic Board: 1890 to 1932, Government Printing Office, Washington, DC (1932).

Smith, $16884 \mathrm{~J}$. Smith, The mystery of rhetorick unveil'd, Peter Clavel, London (1688).

Spindler, 19784 L. S. Spindler, Menominee. In W. C. Sturtevant \& B. G. Trigger (eds.). Handbook of North American Indians, vol. 15: Northeast (pp. 708-724). Washington, DC: Smithsonian Institution, 1978.

Sprague, 1998 R. Sprague, Palouse. In W. C. Sturtevant \& D. W. Walker (eds.) Handbook of North American Indians, vol. 12: Plateau (pp. 352-359). Washington, DC: Smithsonian Institution, 1998.

Sturtevant, $1971 \varangle$ W. C. Sturtevant, Smithsonian plans new Native American handbook, Indian Historian 4 (1971), pp. 5-8.

Sturtevant, 1978- W W. C. Sturtevant, Handbook of North American Indians, Smithsonian Institution, Washington, DC (1978-).

Swanton, 19524 J. R. Swanton, The Indian tribes of North America. House of Representatives. 81st Congress, 2nd session. House Document No. 383 (Serial Set 11475). Washington, DC: Government Printing Office, 1952.

Third report of the United States Board on Geographic Names: 1890 to 1906, 1906 4 Third report of the United States Board on Geographic Names: 1890 to 1906. (1906). House of Representatives. 59th Congress, 1st session. House Document No. 47 (Serial Set 4984). Washington, DC: Government Printing Office.

United States Board on Geographic Names, 1892 - United States Board on Geographic Names. (1892). House of Representatives. 52nd Congress, 1st session. House Executive Document No. 16 (Serial Set 2949). Washington, DC: Government Printing Office.

Washoe Tribe v. United States, $1970 \varangle$ Washoe Tribe v. United States, 24 Ind. Cl. Comm. 107 (1970).

Wedel, 1978 M. M. Wedel, A synonymy of names for the Ioway Indians, Journal of the Iowa Archeological Society 25 (1978), pp. 49-77.

Wedel, $2001 \varangle$ M. M. Wedel, Iowa. In W. C. Sturtevant \& R. J. DeMallie (eds.). Handbook of North American Indians, vol. 13, part 1: Plains (pp. 432-446). Washington, DC: Smithsonian Institution, 2001.

Woodbury and Woodbury, $1999 \varangle$ R. B. Woodbury and N. F. S. Woodbury, The rise and fall of the Bureau of American Ethnology, Journal of the Southwest 41 (1999), pp. 283-296.

Yu, 2008 A. C. L. Yu, The phonetics of quantity alternation in Washo, Journal of Phonetics 36 (2008), pp. 508-520.

Charles D. Bernholz is the Government Documents Librarian at the University of Nebraska-Lincoln. He has a BA from Northeastern University; an MA from the University of Guelph; and an MLS from the State University of New York at Buffalo. His research interests focus upon treaties created by the Indian Nations and the governments of North America, and upon the development of federal Indian law in the United States and in Canada. 